\title{
FAKTOR YANG MEMPENGARUHI KEKAMBUHAN ORANG DENGAN GANGGUAN JIWA
}

\author{
Emilia Puspitasari ${ }^{1}$ \\ ${ }^{1}$ Akademi Keperawatan Widya Husada Semarang \\ ummu_kifah@yahoo.com
}

\begin{abstract}
Abstrak
Kekambuhan merupakan salah satu permasalah an yang sering terjadi pada pasien gangguan jiwa, Kekambuhan yang dialami pasien gangguan jiwa. pasien skizofrenia mengalami kekambuhan berulang..banyak faktor yang memperngaruhi atau menyebabkan kekambuhan, seperti pola asuh, kepatuhan minum obat dan faktor sosial ekonomi pasien. Penelitian bertujuan untuk mengetahui faktor - faktor yang mempengaruhi kekambuhan pasien. Analisis dilakukan pada 13 klien. Hasil didapatkan mayotitas penyebab kambuh dikarenakan putus obat, kepribadian tertutup, dan kegagalan. penelitian ini merekomendasikan perlu upaya mengatasi faktor -faktor yang dapat mengakibatkan kekambuhan.
\end{abstract}

Kata Kunci: Pola Asuh, Ekspresi Emosi Keluarga, Kekambuhan, Skizofrenia

\begin{abstract}
Recurrence is one of the problems that often occurs in patients with mental disorders, recurrences experienced by psychiatric patients. Schizophrenic patients experience recurrent recurrence .. many factors affect or cause recurrence, such as parenting, medication adherence and socioeconomic factors of the patient. The study aims to determine the factors that influence patient recurrence. Analysis was carried out on 13 clients. The results showed that the major causes of relapse were due to drug withdrawal, closed personality, and failure. this study recommends the need to overcome factors that can cause recurrence.
\end{abstract}

Keywords: Parenting Pattern, Expression of Family Emotion, Recurrence, Schizophrenia

\section{Pendahuluan}

Klien dengan gangguan jiwa mempunyai banyak permasalahan. Lora, dkk, (2011), menjelaskan tentang banyaknya permasalahan yang dialami oleh klien dengan gangguan jiwa diantaranyapenurunan kualitas hidup, masalah sosial, dan pekerjaan.

Skizofrenia adalah pola penyakit psikiatri yang memiliki sindroma klinis dari berbagai keadaan psikopatologis yang sangat mengganggu, melibatkan proses pikir, emosi, gerakan dan tingkah laku. Skizofrenia merupakan gangguan kronik dengan konsekwensi fisik, sosial dan ekonomi. Skizofrenia merupakan bagian dari masalah dalam kesehatan masyarakat yang berpengaruh pada sebagaian besar orang dan kerugian ekonomi diseluruh dunia(Välimäki et al., 2012). Kerugian secara ekonomi yang diakibatkan oleh gangguan jiwa diperkirakan 33 milyar dolar di Amerika Serikat pada tahun 1990. Kebanyakan biaya tersebut dihubungkan dengan konsekwensi gejala psikosis yang mengalami relaps / kekambuhan (Sena, Santos-Jesus, Miranda-Scippa, Quarantini, \& Oliveira, 2003).

Hasmilah (2009) lebih lanjut menjelaskan bahwa klien dengan gangguan jiwa mengalami kekambuhan 4,15\% . Kaunang (2015), sebanyak $23,7 \%$ pasien skizofrenia

mengalami kekambuhan berulang.. banyak faktor yang memperngaruhi atau menyebabkan kekambuhan, seperti pola asuh, kepatuhan minum obat dan faktor sosial ekonomi pasien.

Ketidak patuhan dikaitkan dengan program terapi/ pengobatan, karakteristik pasien, lingkungan dan pemberi pelayanan. Stressor sosial berupalingkungan sosial, pendidikan, pekerjaan, ekonomi, akses pelayanan dan problem interaksi interpersonal(Simanjuntak,

2008)Berdasarkan uraian di atas penulis ingin menggambarkan tentang asuhan keperawatan mengetahui faktor - faktor 
yang mempengaruhi kekambuhan pasien di

\section{Metode}

Metode yang digunakan adalah study kasus pada 13 pasienyang dirawat Diruang ruang Bratasena RSMM Bogor".

Bratasena RSMM Bogor. Data diambil menggunakan data pengkajian.

\section{Hasil}

Tabel 1

Karakteristik klien Pendidikan, Pekerjaan (n:13)

\begin{tabular}{lcc}
\hline \multicolumn{1}{c}{ Demografi dan Karakteristik } & Jumlah & Presentase (\%) \\
\hline Pendidikan & 5 & 38 \\
a. Tinggi & 8 & 62 \\
b. Rendah & 10 & 77 \\
\hline Pekerjaan & 3 & 23 \\
a. Tidak kerja & & 92 \\
b. Bekerja & 12 & 8 \\
\hline Tingkat Ekonomi & 1 & 9 \\
a. Rendah & & \\
b. Tinggi & & \\
\hline
\end{tabular}

Tabel1 menjelaskan tentang karakteristik klien yang dirawat di ruang bratasena RSMM Bogor. Klien lebih banyak berpendidikan rendah sebanyak $62 \%$, dengan status pekerjaan tidak bekerja sebanyak $77 \%$, dan dengan tingkat ekonomi rendah sebanyak 92\%.Tabel 2 menjelaskan tentang karakteristik klien yang dirawat di ruang bratasena RSMM Bogor berdasar diagnosis medis klien. Diagnosa medis klien yang paling banyak adalah skizofrenia Paranoid.

Tabel 2

Diagnosis Medis Klien (n:13)

\begin{tabular}{lcc}
\hline \multicolumn{1}{c}{ Karakteristik } & Jumlah & Persentase (\%) \\
\hline & & 76 \\
Skizofrenia Paranoid & 10 & 15 \\
Psikotik akut & 2 & 7 \\
Skizohebrifenik & 1 & \\
\hline
\end{tabular}

Tabel 3.

Karakteristik Klien Berdasar riwayat putus obat (n:13)

\begin{tabular}{lccc}
\hline & Karakteristik & jml & Persentase $(\%)$ \\
\hline Putus obat & 11 & 85 \\
Kasus baru & 2 & 15 \\
\hline
\end{tabular}

Tabel 3 menjelaskan tentang karakteristik klien yang dirawat di ruang bratasena RSMM Bogor berdasar kepatuhan minum obat. Data menunjukan sebanyak $85 \%$ klien mengalami putus obat 
Tabel 4

Karakteristik Klien Berdasar tipe kepribadian (n:13)

Karakteristik Jumlah Persentase (\%)

\begin{tabular}{lcc}
\hline Terbuka & 2 & 15 \\
Tertutup & 11 & 85 \\
\hline
\end{tabular}

Tabel 4 menjelaskan tentang karakteristik klien yang dirawat di ruang bratasena RSMM Bogor berdasar Tipe kepribadian klien Data menunjukan sebanyak $85 \%$ klien berkepribadian tertutup.

Tabel 5

Karakteristik Klien Berdasar pengalaman tidak menyenangkan (n:13)

\begin{tabular}{lcc}
\hline \multicolumn{1}{c}{ Karakteristik } & Jumlah & Persentase (\%) \\
\hline Kehilangan & 7 & 54 \\
Keinginan tidak tercapai & 9 & 69 \\
Kegagalan & 11 & 85 \\
Permasalahan keluarga & 6 & 46 \\
\hline
\end{tabular}

Tabel 5 menjelaskan tentang karakteristik klien yang dirawat di ruang bratasena RSMM Bogor berdasar pengalaman tidak menyenangkan klien. Data menunjukan bahwa pengalaman tidak menyenangkanterbanyak adalah kegagalan sebanyak $85 \%$ dan kejadian tidak menyenangkan bisa lebih dari satu kejadian..

\section{Pembahasan}

Hasil dari studi kasus didapatkan Klien lebih banyak berpendidikan rendah sebanyak $62 \%$, dengan status pekerjaan tidak bekerja sebanyak $77 \%$, dan dengan tingkat ekonomi rendah sebanyak 92\%.Selain hal tersebut diatas tingkat pendidikan dapat mempengaruhi tingkat percaya diri seseorang. Mancuso et.al (2010) menunjukkan bahwa ada hubungan antara tingkat pendidikan klien dengan pengetahuan dan harga diri yang dimiliki, dan beberapa diantara klien dengan gangguan jiwa juga sering ditemukan masalah gangguan konsep diri harga diri rendah.

Stuart (2013). Menjelaskan pendidikan merupakan sumber penerapan koping untuk mencegah peningkatan masalah kejiwaan dan mempercepat pemulihanya.. Stuart (2013) menyatakan tingkat pendidikan yang lebih tinggi ditemukan lebih sering menggunakan pelayanan kesehatan. Penjelasan diatas menjelaskan bahwa seseorang yang berpendidikan tinggi akan mampu menerapkan koping dalam upaya menyelesaikan masalah ketimbang seseorang dengan pendidikan yang rendah salah satunya dalam pengambilan keputusan penggunaan pelayanan kesehatan.

Klien yang bekerja maupun tidak bekerja mempunyai risiko untuk memiliki harga diri rendah. Menurut Yoo et al (2011) pekerjaan klien dapat berhubungan dengan harga diri dan efikasi diri yang dimiliki klien yang menderita penyakit kronis, klien yang bekerja cenderung mempunyai efikasi diri yang tinggi dibandingkan dengan klien yang tidak bekerja dan klien yang tidak mempunyai pekerjaan cenderung mempunyai harga diri yang rendah.

Menurut Obligasi(2001) dan Cooketal. (2005) klien skizofrenia yang bekerja mempunyai hubungan positif dengan harga diri, mengurangi biaya perawatan kesehatan, mengurangi gejala positif dan negatif, meningkatkan fungsi 
sosial dan mengalami peningkatan kualitas hidup. Beberapa klien skizofrenia sering mengalami kesulita mempertahankan pekerjaan yang cocok hal ini desebabkan oleh kurangnya keterampilankejuruan dansosialklien skizofrenia hal tersebut yang berpengaruh terhadap konsep diri klien.

Friedman, (2010). Menjelaskan tentang karakteristik klien dengan sumber ekonomi rendah kurang dapat untuk memenuhi kebutuhan dasar keluarganya. Stuart (2013), menjelaskan bahwa seseorang dengan penghasilan yang mapan dapat lebih menjaga dirinya dan keluarganya dari gangguan kejiwaan. Penjelasan tersebut menegaskan bahwa tingkat ekonomi berpengaruh terhadap tekanan kebutuhan klien yang dapat meningkatkan stresor klien.

Diagnosis medis klien. Diagnosa medis klien yang paling banyak adalah skizofrenia Paranoid. Lora, dkk, (2011), menjelaskan tentang banyaknya permasalahan yang dialami oleh klien dengan gangguan jiwa diantaranyapenurunan kualitas hidup, masalah sosial, dan pekerjaan, sehingga hal tersebut menjadi faktor kekambuhan bagi klien. Hasmilah (2009) lebih lanjut menjelaskan bahwa klien dengan gangguan jiwa mengalami kekambuhan 4,15\%. Kaunang (2015), sebanyak $23,7 \%$ pasien skizofrenia mengalami kekambuhan berulang.

Kepatuhan minum obat. Data menunjukan sebanyak $85 \%$ klien mengalami putus obat. Baiq (2014) menjelaskan klien ada hubungan antara kepatuhan minum obat dengan kejadian kekambuhan pada klien dengan skizofrenia. Obat berfungsi sebagai pengurang atau penghambat gejala positif atau gejala negatif klien dengan skizofrenia. Banyak sekali penderita skizofrenia yang mengalami klinis dan membutuhkan perawatan akibat tidak menuruti penatalaksanaan yang diberikan(Ayuso-Gutierrez \& del Rio Vega, 1997). Menurut kinon et al., kriteria ketidakpatuhan terhadap pengobatanadalah jika ditemukan salah satu keadaan sebagai berikut: (1) Pasien rawat jalan atau rawat inap dalam 72 jam menunjukkan lebih dua episode dari menoak obat yang diresepkan baik secara aktif atau pasif; adanya bukti atau kecurigaan menyimpan atau meludahkan obat yang diberikan; menunjukkan keragu-raguan terhadap obat yang diberikan. (2)Pasien rawat inap dengan riwayat tidak patuh pada pengobatan sewaktu rawat jalan minimal tidak patuh selama 7 hari dalam sebulan. (3)Pasien rawat jalan dengan riwayat ketidakpatuhan yang sangat jelas seperti sudah pernah dilakukan keputusan untuk mengawasi dengan ketat oleh orang lain dalam waktu sebulan. (4) Pasien rawat inap yang mengatakan dirinya tidak dapat menelan obat-obatan walaupun tidak ditemukan kondisi medis yang dapat mengakibatkan hal tersebut.

Tipe kepribadian klien Data menunjukan sebanyak $85 \%$ klien berkepribadian tertutup.tipe kepribadian berbanding lurus dengan kemampuan seseorang mengatasi masalah. Tipe kepribadian tertutup sering mengalami kesuliatan dalam beradaptasi dan mengatasi masalah. Azizah (2016) kepribadian introvert memiliki tingkat stres yang lebih tinggi dibandingkan responden dengan tipe kepribadian ekstrovert.

Data menunjukan bahwa pengalaman tidak menyenangkan terbanyak adalah kegagalan sebanyak $85 \%$ dan kejadian tidak menyenangkan bisa lebih dari satu kejadian.tingginya stresor yang dialami seseorang akan berpengaruh terhadap kemampuan seseorang dalam mengatasi stress. Ketidak mampuan seseorang untuk mengelola stresor yang ada akan berdampak pada tingkat stress seseorang. Stuart (2013) bahwa faktor psikologis, yang meliputi konsep diri, intelektualitas, kepribadian, moralitas, pengalaman masa lalu, koping dan keterampilan komunikasi secara verbal mempengaruhi perilaku seseorang dalam hubungannya dengan orang lain. Pengalaman masa lalu berupa 
kehilangan dan kegagalan yang dialami klien mempengaruhi respon individu dalam mengatasi stresornya, klien menjadi tidak percaya diri dalam berhubungan dengan orang lain. Kondisi ini akan membuat individu lebih cenderung merasa rendah diri dan menarik diri dari orang lain dan lingkungannya

\section{Simpulan dan Saran}

Penyebab kambuh dikarenakan putus obat, kepribadian tertutup, dan kegagalan. penelitian ini merekomendasikan perlu upaya mengatasi faktor -faktor yang dapat mengakibatkan kekambuhan.

\section{Daftar pustaka}

Azizah (2016) Perbedaan antara tipr kepribadian terbuka dan tertutup dengan tingkat stress pada mahasiswa fakultas hukum universitas muhamadyah surakarta. Diakses 5 Agustus 2016

Baiq (2014) , Hubungan Kepatuhan Minum Obat Dengan Prevalensi Kekambuhan Pada Pasien Skizofrenia Di Rsj Aceh. Stikes Aisyah Yogyakarta. Diakses tanggal 2 Agustus 2016

Friedman, M.M. (2010). Keperawatan keluarga Riset teori dan praktek. Jakarta: EGC.

Hasmilah (2009) Pengaruh Family Psiko Edukasi Terhadap Kekambuhan Klien Dengan Skizofrenia. Universitas Indonesia. Jakarta. Diakses tanggal 2 Agustus 2016.

Ireine Kaunang, (2015), “ Hubungan Kepatuhan Minum Obat Dengan Prevalensi Kekambuhan Pada Pasien Skizofrenia Yang Berobat Jalan Di Ruang Poliklinik Jiwa Rumah Sakit Prof Dr. V. L. Ratumbuysang Manado. ejournal keperawatan (e-Kp) Volume 2.
Nomor 2. Mei 2015. Diakses tanggal 2 Agustus 2016

Mancuso, C.A., Sayles, W., Allegrante, J.P. (2010). Knowledge, Attitude, and Self-Efficacy in Asthma SelfManagement and Quality of Life. Journal of Asthma, 47:883-888. DOI:

10.3109/02770903.2010.492540

Stuart, G. W. (2013). Principles and Practice of Psychiatric Nursing (9 ed.). Missouri: Mosby, Inc.

RISKESDAS (2013). Laporan Hasil Riset Kesehatan Dasar tahun 2013. Badan peelitian dan Pengembangan Kesehatan Kementerian Kesehatan RI. 